\title{
Review of Residential Low-Load HVAC Systems
}

\section{SA Brown}

BA Thornton

SH Widder

MC Baechler, Project Manager

September 2013

\section{Pacific Northwest}

NATIONAL LABORATORY

Proudly Operated by Battelle Since 1965 


\title{
DISCLAIMER
}

This report was prepared as an account of work sponsored by an agency of the United States Government. Neither the United States Government nor any agency thereof, nor Battelle Memorial Institute, nor any of their employees, makes any warranty, express or implied, or assumes any legal liability or responsibility for the accuracy, completeness, or usefulness of any information, apparatus, product, or process disclosed, or represents that its use would not infringe privately owned rights. Reference herein to any specific commercial product, process, or service by trade name, trademark, manufacturer, or otherwise does not necessarily constitute or imply its endorsement, recommendation, or favoring by the United States Government or any agency thereof, or Battelle Memorial Institute. The views and opinions of authors expressed herein do not necessarily state or reflect those of the United States Government or any agency thereof.

\author{
PACIFIC NORTHWEST NATIONAL LABORATORY \\ operated by \\ BATTELLE \\ for the \\ UNITED STATES DEPARTMENT OF ENERGY \\ under Contract DE-AC05-76RL01830
}

Printed in the United States of America
Available to DOE and DOE contractors from the Office of Scientific and Technical Information,
P.O. Box 62, Oak Ridge, TN 37831-0062;
ph: (865) 576-8401
fax: $(865)$ 576-5728
email: reports@adonis.osti.gov

\begin{abstract}
Available to the public from the National Technical Information Service, U.S. Department of Commerce, 5285 Port Royal Rd., Springfield, VA 22161 ph: (800) 553-6847 fax: $(703) 605-6900$ email: orders@ntis.fedworld.gov online ordering: http://www.ntis.gov/ordering.htm
\end{abstract}

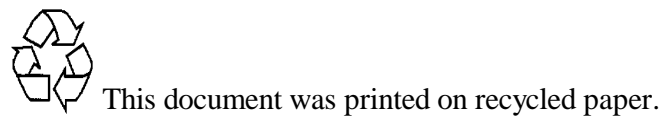


PNNL-23017

Letter Report

\title{
Review of Residential Low-Load HVAC Systems
}

\author{
SA Brown \\ BA Thornton \\ SH Widder \\ MC Baechler, Project Manager
}

September 2013

Prepared for

the U.S. Department of Energy

under Contract DE-AC05-76RL01830

Pacific Northwest National Laboratory

Richland, Washington 99352 


\section{Introduction}

In an effort to achieve significant reductions in residential energy consumption, some new homes are being built with air-sealed, highly insulated envelopes (e.g., R-40 walls and triple-pane windows) that dramatically reduce heat losses and gains through the building shell. These low-load homes (which typically have energy-efficient lighting and appliances in addition to highly insulated envelopes) have space heating and/or space cooling loads that are significantly lower than those of an average home. Although multiple descriptions exist for what constitutes a low-load home, a common definition is a home with maximum space heating and cooling design loads of 10 British thermal units per hour per square foot $\left(\mathrm{Btu} / \mathrm{h} / \mathrm{ft}^{2}\right)$ of conditioned space (Rosenbaum 2010; Stecher 2011). Based on this definition, the maximum design load for low-load homes with 1,200-2,400 $\mathrm{ft}^{2}$ of conditioned floor area is 12,000 $24,000 \mathrm{Btu} / \mathrm{h}$ (1-2 tons). For most of the year, actual loads are significantly lower than the design load, so partial heating and/or cooling loads of less than $12,000 \mathrm{Btu} / \mathrm{h}$ are common.

Conventional central heating, ventilation, and air conditioning (HVAC) systems (e.g., furnaces, boilers, heat pumps, and air conditioners) are traditionally designed to serve homes with space conditioning loads larger than this definition of low-load. The use of type of this equipment in low-load homes can result in system inefficiencies and comfort issues. As a result, alternative solutions (e.g., space conditioning from multiple point sources) are needed to serve low-load homes. Anecdotal evidence (described in the Conventional HVAC Systems section of this report) indicates that large manufacturers will not develop smaller-capacity conventional HVAC equipment targeted at low-load homes without evidence that there is a significant and growing market. Until low-load homes represent a large enough portion of the housing market for major HVAC manufacturers to offer small-capacity, point-source systems, the need for low-load HVAC will be met by overseas manufacturers or U.S. manufacturers that serve niche markets.

In support of the U.S. Department of Energy's (DOE's) Building America Program, Pacific Northwest National Laboratory (PNNL) conducted an investigation to inventory commercially available HVAC technologies that are being installed in low-load homes. The first step in this investigation was to conduct a review of published literature to identify low-load HVAC technologies available in the United States and abroad, and document the findings of existing case studies that have evaluated the performance of the identified technologies. To conduct this literature review, PNNL consulted publications and presentations on low-load HVAC from a variety of sources, including:

- the Building America Program (Summer 2012 Technical Update Meeting, Expert Meeting Reports, individual case studies, and special research projects)

- presentations given at industry conferences, such as the Northeast Sustainable Energy Association's Building Energy 2012 and the Energy \& Environmental Building Alliance's 2012 Excellence in Building Conference \& Expo

- articles from building science forums and media outlets such as GreenBuildingAdvisor.com

- information about related programs, such as the Passive House Institute U.S. (PHIUS) and the Northwest Energy Efficiency Alliance's (NEEA’s) Northwest Ductless Heat Pump Project

- equipment descriptions and specifications from U.S. and international manufacturer websites. 
The literature review identified several HVAC solutions that are appropriate for low-load homes. A variety of decentralized point-source heating and cooling technologies combined with separate ventilation strategies are being successfully applied. Electric solutions, such as ductless mini-split heat pumps (the dominant solution) and electric resistance heating, as well as gas solutions, such as direct-vent wall furnaces (DVWFs), have been demonstrated in several climate zones. There are also alternative central systems, such as gas combination ("combi") systems (which provide domestic hot water and space heating from the same equipment) and air-to-water heat pumps (which provide space cooling in addition to space heating and domestic hot water). Recently, new types of central HVAC equipment have been introduced with part-load operating capacities that are appropriate for low-load homes without a significant sacrifice in equipment efficiency. Such systems include modulating furnaces and boilers and variable-capacity air conditioners and heat pumps. Energy-recovery or heat-recovery ventilators and/or exhaust fans are often used to provide outdoor air ventilation in these air-sealed homes and may also provide distribution of space conditioning in homes served with point-source rather than central equipment.

While there are HVAC solutions in use for low-load homes, there is a need for guidance and research on selection, design, installation, operation and cost-effectiveness of these HVAC systems to support continued development and market penetration of highly energy efficient residential homes.

This report presents the findings of the literature review, identifies gaps in the literature or technical understanding that must be addressed before low-load HVAC technologies can be fully evaluated, and introduces PNNL's planned research and analysis for this project to address identified gaps and potential future work on residential low-load HVAC systems.

\section{Conventional HVAC Systems}

HVAC systems provide a variety of services to keep the conditioned space comfortable for occupants, including heating, cooling, ventilation, and humidity control. HVAC systems can provide conditioned air via central, ducted systems (such as conventional, non-modulating furnaces, air conditioners, and heat pumps) or point-of-use systems (such as wall heaters or window air conditioners) that supply conditioned air directly into a particular part of a home. The current U.S. HVAC market is dominated by central ducted systems, as shown in Figures 1 and 2 (data from EIA 2012). The figures show that roughly threequarters of heating and cooling equipment are central, forced air systems. 


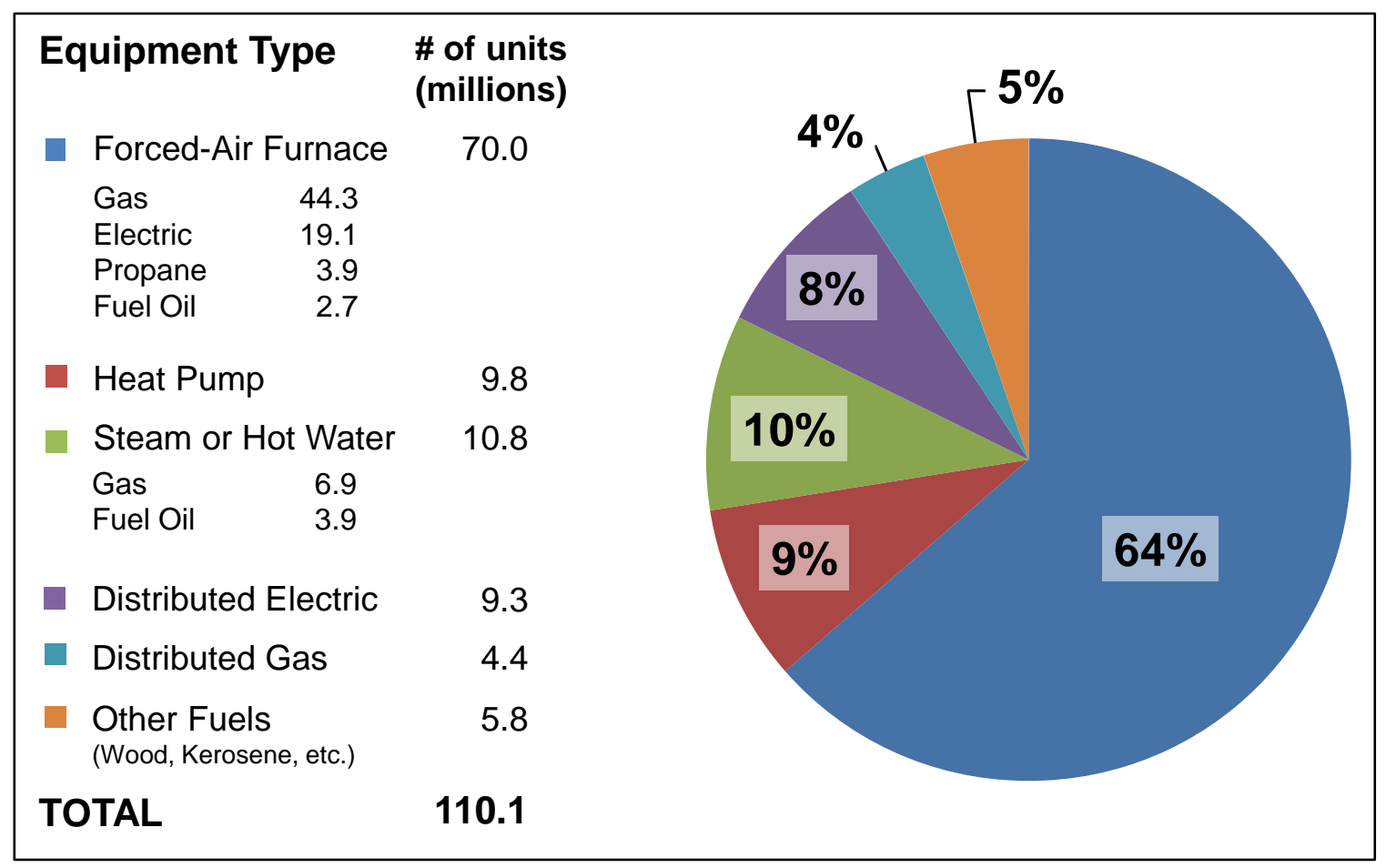

Figure 1. Primary Heating Equipment in the U.S. Market (EIA 2012)

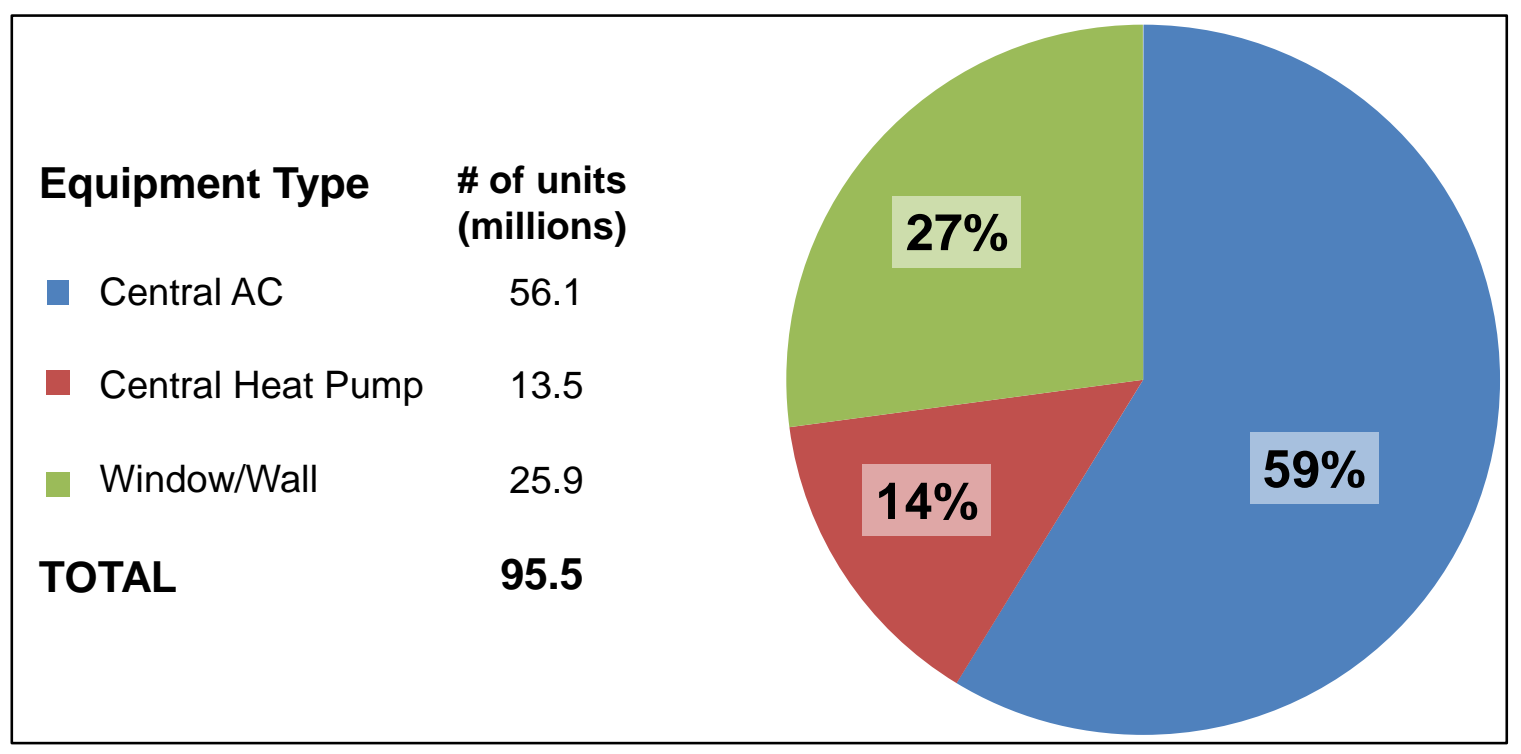

Figure 2. Primary Cooling Equipment in the U.S. Market (EIA 2012)

Conventional central HVAC systems are typically sized to provide heating or cooling for existing homes with design heating loads that range from 40,000 to $100,000 \mathrm{Btu} / \mathrm{h}$ and design cooling loads that range from 1.5 to 5 tons. While the smallest of these units are sized appropriately for the design loads of larger low-load homes (see Table 2 below), the majority of conventional-size HVAC systems are likely to satisfy the heating or cooling temperature needs of a low-load home very quickly, turning on and then 
abruptly shutting off (a process known as "short cycling"). Short cycling decreases the efficiency of HVAC systems and can result in uncomfortable conditions for occupants-for example, a short blast of conditioned air rather than a more steady supply of conditioned air at a lower flow rate. When cooling, these short cycle times can also result in poor humidity control in humid climates, which can lead to comfort issues as well as indoor air quality concerns. ${ }^{1}$

A sample of typical residential central HVAC equipment sizes that are available in the United States was gathered from three major U.S. manufacturers (Carrier, Lennox, and Trane). While there are many other significant manufacturers including Goodman, Rheem, York, Nordyne, and others, the selected sample had a total 2008 market share of $58 \%$ of the gas furnace market and $51 \%$ of the unitary air conditioner and heat pump market in the United States (DOE 2011) and provides a reasonable representation of HVAC equipment that is widely available to U.S. consumers. (Major manufacturers have nationwide networks of distributors, whereas niche manufacturers who serve developing markets like low-load housing tend to be located only in larger cities.) Table 1 lists the minimum capacities for single-stage ${ }^{2}$ air conditioners, heat pumps, gas ${ }^{3}$ furnaces, and boilers offered by the three manufacturers.

Table 1. Conventional Central HVAC Equipment

\begin{tabular}{|l|c|c|}
\hline \multicolumn{1}{|c|}{ Type } & Minimum Cooling Capacity & Minimum Heating Capacity \\
\hline Air conditioners (single-stage) & $\sim 18,000 \mathrm{Btu} / \mathrm{h}(1.5$ tons $)$ & N/A \\
\hline Heat pumps (single-stage) & $\sim 18,000 \mathrm{Btu} / \mathrm{h}(1.5$ tons $)$ & $\sim 18,000 \mathrm{Btu} / \mathrm{h}$ \\
\hline Gas furnaces (single-stage) & N/A & $\sim 40,000 \mathrm{Btu} / \mathrm{h}$ \\
\hline Boilers $^{\mathrm{a}}$ & N/A & $\sim 30,000 \mathrm{Btu} / \mathrm{h}$ \\
\hline
\end{tabular}

(a) Carrier and Lennox only; Trane does not offer boilers on its residential equipment website.

Table 2 shows whole-house heating or cooling loads based on typical home sizes and a design load of $10 \mathrm{Btu} / \mathrm{h} / \mathrm{ft}^{2}$ (the maximum design load for a low-load home). It is important to understand that for both low-load and conventional homes the majority of hours when heating or cooling actually occur the loads are at well less than the design load. However, the smallest single-stage gas furnaces are significantly oversized for the design loads of the three low-load homes; the smallest single-stage air conditioners and heat pumps are appropriately sized for the design loads of the larger (1,800-2,400 $\left.\mathrm{ft}^{2}\right)$ low-load homes. Hence, if conventional equipment is used in low-load homes it will always be oversized on the heating side and often oversized on the cooling side which will exacerbate the problems associated with shortcycling noted above.

\footnotetext{
${ }^{1}$ High humidity for extended periods of time can lead to mold and mildew growth on and in building components. Elevated mold concentrations have been associated with increased occurrence and severity of respiratory issues (EPA 2012).

${ }^{2}$ More recently introduced multistage, modulating, and variable-capacity equipment can achieve lower part-load operation, which can reduce or eliminate short cycling and is more appropriate for low-load homes. This type of equipment is discussed in the HVAC Options for Low-Load Homes section of this report.

${ }^{3}$ Electric furnaces can also be used as the primary heat source, with or without being integrated with a cooling option. However, an electric furnace uses much more electricity for heating than a heat pump, resulting in higher electricity bills, and this type of furnace is not commonly used. Electric resistance is more commonly used as a supplemental heating system or a point-source heating system.
} 
Table 2. Whole-House Loads (Btu/h) at Fractions of Design Load

\begin{tabular}{|c|c|c|c|c|}
\hline \multirow{2}{*}{$\begin{array}{c}\text { \% of Design } \\
\text { Load }\end{array}$} & \multirow{2}{*}{$\mathbf{B t u} / \mathbf{h} / \mathbf{f t}^{2}$} & \multicolumn{3}{|c|}{ Size of Home $\left(\mathrm{ft}^{2}\right)$} \\
\hline & & 1,200 & 1,800 & 2,400 \\
\hline $100 \%$ & 10 & 12,000 & 18,000 & 24,000 \\
\hline $90 \%$ & 9 & 10,800 & 16,200 & 21,600 \\
\hline $80 \%$ & 8 & 9,600 & 14,400 & 19,200 \\
\hline $70 \%$ & 7 & 8,400 & 12,600 & 16,800 \\
\hline $60 \%$ & 6 & 7,200 & 10,800 & 14,400 \\
\hline $50 \%$ & 5 & 6,000 & 9,000 & 12,000 \\
\hline $40 \%$ & 4 & 4,800 & 7,200 & 9,600 \\
\hline $30 \%$ & 3 & 3,600 & 5,400 & 7,200 \\
\hline $20 \%$ & 2 & 2,400 & 3,600 & 4,800 \\
\hline $10 \%$ & 1 & 1,200 & 1,800 & 2,400 \\
\hline
\end{tabular}

As demonstrated by the data presented in Tables 1 and 2, the single-stage central HVAC equipment that currently dominates the U.S. market is oversized for low-load homes. This issue was pointed out by multiple speakers at the Building America Summer 2012 Technical Update Meeting (Ruiz 2012). One of the comments regarding low-load HVAC from the Building America Technical Update Meeting asserted that "anecdotal evidence from manufacturers says it is more expensive per Btu to build a smaller furnace and perceived demand isn't great enough to instigate the production of these products. The problem isn't a technical challenge, but a market challenge" (NREL 2012). In a December 2012 seminar, Dr. John Straube of Building Science Corporation described this issue as a "chicken-and-egg-type" conundrum, where manufacturers do not sell low-capacity equipment "because no one is buying it," yet it is impossible for anyone to buy equipment that is not available (Bailes 2012).

PNNL spoke with a sales engineer from Trane and asked whether a two-stage, condensing gas furnace could be built with an output suitable for a low-load home, such as $8,000 \mathrm{Btu} / \mathrm{h}$ at low fire and $12,000 \mathrm{Btu} / \mathrm{h}$ at high fire. ${ }^{4}$ The engineer said that such a product could be built, but that none of the major HVAC manufacturers offer a furnace of such small size because there is not a large enough market for it. According to the engineer, in order to offer an 8,000-12,000 Btu/h furnace, there would need to be enough demand to justify manufacturing tens of thousands of units per year. Another challenge is that the parts for standard furnace sizes are readily available due to high demand, while parts (e.g., burners) for smaller sizes are not readily available and would have a high price due to their custom nature. PNNL also spoke with a representative from Lennox, who said that low-load homes are "in the small margin [of the housing market]." 5

These perspectives suggest that major HVAC manufacturers will not become interested in offering conventional central equipment with smaller capacities until hard numbers can show a significant

\footnotetext{
${ }^{4}$ Personal communication between a Trane sales engineer and SA Brown (PNNL) on January 2, 2013, Richland, Washington.

${ }^{5}$ Personal communication between a representative of Lennox Applications Group and SA Brown (PNNL) on January 2, 2013, Richland, Washington.
} 
low-load market size or at least rapid growth in the market. At the Building America Summer 2012 Technical Update Meeting, Dr. Straube stated that low HVAC loads are becoming common due to improved envelopes and an increasing number of people living in multifamily housing (e.g., apartments and row houses) and smaller single-family homes (NREL 2012; Straube 2012). Another presenter at the Technical Update Meeting (Ben Schoenbauer of the NorthernSTAR Building America Partnership) stated that "low load homes are more common than ever" (Schoenbauer 2012). While the experts in the field clearly agree that the low-load market size is increasing, PNNL did not find information quantifying the number of low-load homes that currently exist in the United States or the rate at which new low-load homes are being built. A characterization of the low-load housing market is beyond the scope of this project, but may be a good topic for future research.

\section{HVAC Options for Low-Load Homes}

Some foreign manufacturers have begun to offer technologies with modular designs that are more commensurate with the design load of low-load homes. Technologies from Asia and Europe, such as ductless mini-splits and small boilers, are becoming available in the U.S. market. Some point-source equipment types that are applied in low-load homes have been in use for a long time, such as electric baseboards and electric wall heaters.

Most of the smaller-capacity technologies being applied to low-load homes provide heating or cooling at a single point in the home, unlike central ducted systems that distribute heated or cooled air to multiple locations (in some cases, every room). However, heating or cooling from a point source can be distributed throughout the home by the mechanical ventilation system. Mechanical ventilation is often required to ensure adequate indoor air quality in low-load homes due to their well-sealed envelopes. The circulation of air provided by the mechanical ventilation system also helps to improve temperature uniformity in the home. Some low-load HVAC systems (e.g., ductless multi-splits and hydronic space heating systems) use multiple point-source emitters (e.g., fan coil units and radiators, respectively) to simultaneously serve multiple rooms in the home.

PHIUS, which sponsors Passive House design and certifies Passive Houses, has a listing of 51 Passive Houses that have been certified in the United States. (PHIUS 2012). These homes generally have heating and cooling loads that are much lower than the definition of "low load" (a maximum design load of $10 \mathrm{Btu} / \mathrm{h} / \mathrm{ft}^{2}$ ) presented above. The HVAC system types are listed for 39 of these homes in the more detailed individual home descriptions accessible from the PHIUS website (PHIUS 2012). Table 3 shows the different system types used in these homes. Mini-split heat pumps and electric resistance heating are the most commonly used systems. Some heat pumps were not described sufficiently to distinguish conventional central heat pumps from mini-splits. 
Table 3. U.S. Passive House HVAC System Types (PHIUS 2012)

\begin{tabular}{|c|c|}
\hline Equipment Type & Number \\
\hline Ductless Mini-Split Heat Pump & 17 \\
\hline Electric Resistance Heating & 7 \\
\hline Heat Pump (unknown) & 6 \\
\hline Air-to-Water Heat Pump & 3 \\
\hline Combi System & 2 \\
\hline Solar Hot Water & 2 \\
\hline Energy Recovery Ventilator & 1 \\
\hline Ground-Source Heat Pump & 1 \\
\hline Total & 39 \\
\hline
\end{tabular}

Because the heating or cooling loads are so small in low-load homes, point-source systems are often designed with one centrally located point source per floor. However, the conditioned air still needs to be moved throughout the home. Without the ductwork of central forced-air systems, other distribution strategies must be used to minimize temperature differences throughout the home to maintain occupant comfort. $^{6}$ Almost all low-load homes have a dedicated mechanical ventilation system to provide adequate indoor air quality because their well-sealed envelopes minimize air leakage. Heat/energy recovery ventilators (HRVs/ERVs) are often used to reduce the energy demand for conditioning ventilation air by transferring sensible heat (HRV) or sensible heat and moisture (ERV) between the incoming outdoor air and exiting exhaust air. A common conventional setup for HRVs/ERVs is to exhaust air from the most odor-prone rooms of the house (e.g., bathrooms, laundry rooms, and kitchens) and supply tempered outdoor air to the bedrooms and main living spaces. For low-load homes in which point-source heating/cooling is supplied only to central spaces (e.g., the living room and the upstairs hallway), an alternative strategy is to have the HRV/ERV supply tempered outdoor air to the central spaces and exhaust from the peripheral rooms (e.g., bedrooms). This strategy helps to pull conditioned air through the home and minimize temperature differences in rooms without point-source supply. Other techniques for minimizing temperature differences include the use of a small exhaust fan and short runs of small-diameter ducts to pull air from the directly conditioned space (e.g., the first-floor living room) into bedrooms (CARB 2010a) and the use of open doors and passive interior wall vents to take advantage of natural convection (Stecher 2012). Another solution is the use of distributed systems such as electric baseboards or wall heaters, as shown in Table 3.

Mechanical systems in a home need to provide several services depending on climate, including space heating, space cooling, humidity control, ventilation, and domestic hot water (DHW). The technologies described below serve one or more, but typically not all, of these functions. Factors that influence the optimum combination of technologies used to provide HVAC (and potentially DHW) services in a low-

\footnotetext{
${ }^{6}$ One commonly referenced standard for temperature-related comfort is the Air Conditioning Contractors of America's (ACCA's) Manual RS: Comfort, Air Quality, and Efficiency by Design (Rutkowski 1997). For residential single-zone systems, Manual RS suggests a maximum room-to-room temperature difference of $4^{\circ} \mathrm{F}$ during the heating season and $6^{\circ} \mathrm{F}$ during the cooling season.
} 
load home include the differing heating, cooling, and humidity demands of various climate zones; fuel type availability; system life-cycle cost (tradeoffs between installed cost and operating costs); and occupant comfort. The following sections provide a summary and short description of available low-load HVAC technologies, including research results evaluating the performance of installed equipment and identification of key implementation issues.

Mechanical ventilation equipment, including HRVs/ERVs and exhaust fans, is typically applied in low-load homes for air quality and temperature distribution. Cooling equipment is almost always electric, while heating equipment can be electric or natural-gas-fired. Other fossil fuel sources (e.g., propane) may be used with some of this equipment. Other equipment types that have been applied to particular low-load home projects include ground source heat pumps and solar hot water. These systems (which tend to be highly customized) are more expensive and are therefore not likely to be widely used. For this reason, these systems are not described further in this report.

The literature review suggests that the following system types are most commonly used in low-load homes:

- mechanical ventilation, including balanced (with an HRV/ERV) and exhaust-only strategies

- electric options

- ductless mini-split heat pumps

- lower-cost electric resistance heating and window-mount air conditioners

- variable-capacity central split-system air conditioners and heat pumps

- air-to-water heat pumps

- gas options (heating only; if cooling is needed other equipment is required)

- direct-vent wall furnaces

- combination DHW and heating systems

- two-stage and fully modulating central gas furnaces

- modulating boilers.

\section{Mechanical Ventilation}

HRVs/ERVs are used to provide mechanical ventilation in tightly air-sealed homes to ensure adequate indoor air quality. Thirty-six of the 39 PHIUS homes in Table 3 have an HRV/ERV (PHIUS 2012). HRVs/ERVs reduce the energy demand for conditioning ventilation air by transferring sensible heat (HRV) or sensible heat and moisture (ERV) between the incoming outdoor air and exiting exhaust air. ERVs are generally used in humid climates to recover energy used to dry the outside air in addition to recovering the energy needed to cool or heat the air.

HRVs/ERVs often supply fresh air to living spaces (e.g., living rooms and bedrooms). In a low-load home with point-source heating only in central spaces (e.g., the family room and central upstairs hallway), supplying tempered outdoor air to bedrooms during the winter could lead to uncomfortably cool temperatures in those rooms. An alternative strategy is to supply tempered outdoor air to the directly 
heated space and exhaust air from the bedrooms, helping to pull heated air from the point source (e.g., a mini-split head) throughout the home.

The importance of co-locating the supply air from the HRV/ERV and the space heating point source is discussed in a study performed by the Consortium for Advanced Residential Buildings (CARB) on a home located in the Katywil Community of Colrain, Massachusetts (CARB 2010b). This two-story home is served by ductless mini-splits with one indoor fan coil (or "head") per floor and an HRV for mechanical ventilation and air distribution. The downstairs mini-split head is located in a bedroom while the downstairs HRV supply air is located in the central hallway, which resulted in uncomfortably cold conditions in the hallway (CARB 2010b). Despite the tempering provided by an HRV/ERV, very cold ambient air temperatures (such as those present during the Massachusetts heating season) can lead to supply air temperatures that are uncomfortable for occupants. This situation is exacerbated if the space receiving the supply air is isolated from the space with the point-source heating. For example, if the door to the downstairs bedroom in the Katywil home was left closed for long periods of time, the room could warm up and satisfy the thermostat for the mini-split, while the hallway remains cold.

Interior door position (open vs. closed) is another important factor that influences temperature distribution in homes heated by point-source systems serving only central spaces. At the Building America Expert Meeting on Simplified Space Conditioning Strategies for Energy Efficient Houses, IBACOS, Inc., presented data from a two-week test with a mini-split system conducted during February 2011 in their unoccupied cold-climate test house (Stecher 2011). When conditioned air was supplied to the second-floor hallway with all bedroom doors closed, the bedrooms were on average $7^{\circ} \mathrm{F}$ cooler than the hallway. Within 3 hours of opening the doors, the bedroom temperatures stabilized to within $\pm 1^{\circ} \mathrm{F}$ of the hallway.

As the research performed by CARB and IBACOS demonstrates, the mechanical ventilation systems of low-load homes can be harnessed to aid with temperature distribution for point source heating/cooling. However, care must be taken with respect to the positioning of the point source heating/cooling and supply/exhaust locations. Keeping interior doors open whenever possible helps to minimize temperature differences; passive vents in interior walls/doors can help minimize temperature differences when privacy is desired and interior doors have to be closed.

\section{Electric Options}

There are electric options that provide heating and cooling, as well as heating-only options. The most prevalent low-load system type, as demonstrated in Table 3, is the ductless mini-split heat pump, which provides heating and cooling. Another alternative, electric resistance, provides only heating and comes in a variety of different equipment types, such as baseboard, wall heaters, inline duct heaters, or wire coils added to an HRV/ERV. Air-to-water heat pumps can provide DHW, hot water for space heating, and cold water for space cooling. 


\section{Ductless Mini-Split Heat Pumps}

Ductless mini-split heat pumps ${ }^{7}$ rely on a refrigerant cycle to transfer heat to or from a home, similar to conventional, ducted split-system heat pumps. However, ductless mini-split heat pumps, as suggested by their name, differ with regard to how the conditioned air is supplied to the home. Conventional split-system heat pumps have one indoor coil in an air-handling unit and use forced-air distribution through ductwork to deliver conditioned air to various zones within a home. In contrast, ductless mini-splits connect one or more indoor coils (often referred to as "heads" or "fan coils") to a single outdoor unit (i.e., the condenser), with each head having its own refrigerant loop. Conditioned air is provided directly to the rooms in which the heads are located, without the use of ductwork. Mini-split systems with more than one indoor head (sometimes referred to as "multi-split" systems) enable specific zones to be conditioned independently because each indoor unit has its own thermostat. Multi-split systems with up to eight heads are available, but the majority of multi-split installations use two to four heads (in shorthand notation, these systems are 2:1, 3:1, and 4:1 multi-splits, respectively).

The outdoor units of ductless mini-split systems have an inverter-driven ${ }^{8}$ compressor, which alters the amount of refrigerant circulating through the indoor units (and hence, the heating/cooling capacity) in response to varying heating/cooling loads within the home. Inverter systems operate the compressor at lower speed as the load decreases, and as a result use less energy than they would if simply cycling on and off to meet the same load.

As an example of typical mini-split capacities that are available, Mitsubishi offers 1:1 mini-split systems with rated cooling capacities from 9,000-36,000 Btu/h (Mitsubishi 2012). The capacity of the units can go down to approximately $30 \%$ of the rated amount; the 9,000 Btu/h-rated unit has a minimum cooling capacity of 2,800 Btu/h (Mitsubishi 2009a), which is a suitable range for the smallest part-load conditions that could be encountered in low-load homes. The smallest multi-split system offered by Mitsubishi is a 2:1with a rated total capacity of $20,000 \mathrm{Btu} / \mathrm{h}$; the rated capacity of the smallest indoor unit that can be used on this system is $6,000 \mathrm{Btu} / \mathrm{h} .^{9}$

Due to the point-source nature of the heating/cooling provided by mini-splits, temperature distribution throughout the home is a concern. A common recommendation is to provide one indoor unit per floor, with the downstairs unit mounted in the main living space and the upstairs unit mounted in a central hallway. Transformations, Inc., (a builder located in Townsend, Massachusetts) has built 18 low-load homes that are each heated and cooled with a pair of 12,000 Btu/h 1:1 mini-splits, with an installed cost of \$5,000-\$6,000 total for both units (Holladay 2012). ${ }^{10}$ Despite skepticism that unheated bedrooms would be cold, the homeowners have been very pleased with the evenness of indoor temperatures and in many cases have not needed to use the upstairs unit until the outdoor temperature dropped below $20^{\circ} \mathrm{F}$.

\footnotetext{
${ }^{7}$ Many variations of this term exist in published literature, including: ductless heat pumps, mini-split heat pumps, ductless mini-splits, and mini-splits.

${ }^{8}$ The term "inverter-driven" is synonymous with "variable-frequency drive." AC electricity supplied to the house is rectified to DC, and then inverted back to AC at any desired frequency. Adjusting the AC frequency controls the speed of the compressor's motor, and hence the amount of refrigerant circulated through the indoor units.

${ }^{9}$ Personal communication between Mark Kuntz (Mitsubishi Electric) and SA Brown/BA Thornton (PNNL) on December 11, 2012, Richland, Washington.

${ }^{10}$ According to the Northwest Ductless Heat Pump Project (an initiative by the NEEA to displace zonal baseboard heating with mini-split heating in existing homes), the average installed cost of a 1-to-1 mini-split system is $\$ 3,000$ $\$ 5,000$ (NEEA 2012).
} 
Transformations found that the primary need for the upstairs unit is for cooling in the summer. While warm air from a single downstairs unit naturally rises, cool air does not, resulting in a hot upstairs during the summer in a home with only a downstairs indoor unit.

The most common non-thermal issues reported by homeowners with mini-splits are aesthetics and fan noise of the wall-mounted indoor units; some homeowners also report being annoyed/distracted by the blowing air from the indoor units (CARB 2010b, Baylon et al. 2012). To help combat the aesthetics and comfort issues of wall-mounted indoor units, some mini-split models come with indoor units that are designed to be concealed within short runs of ductwork. The installation cost of the concealed-ducted versions is higher than the wall-mounted units and additional fan energy is required to move air through the duct and distribution grille.

As with all heat pumps, the capacity and heating efficiency of mini-splits decreases with decreasing outdoor air temperature, so performance in extremely cold climates is a concern. Traditionally, heat pumps are supplied with backup electric resistance elements to maintain comfort even in very cold conditions, although this results in reduced efficiency of the heat pump. Recently, manufacturers have worked to improve ductless heat pump technology, enabling reasonable heating capacity and efficiency in subzero temperatures with little or no supplemental heat. According to Carter Scott (President of Transformations, Inc.), the 12,000 Btu/h Mitsubishi mini-splits his firm uses can provide 10,000 Btu/h of heat with a coefficient of performance (COP) of 1.8 at an outdoor temperature of $0^{\circ} \mathrm{F}$ (Holladay 2012). Mitsubishi's 9,000 Btu/h and $12,000 \mathrm{Btu} / \mathrm{h}$ units automatically shut down at $-18^{\circ} \mathrm{F}$ and restart at $-13^{\circ} \mathrm{F}$ (Mitsubishi 2009a, 2009b) and can provide $60 \%$ of their rated heating output at $-13^{\circ} \mathrm{F}$ (Kuntz 2012). Testing performed by the NEEA on a Mitsubishi 12,000 Btu/h unit in Helena, Montana, showed that the unit consistently maintained supply air temperatures of $105^{\circ} \mathrm{F}$ with $\mathrm{COP}$ values of $1.5-2.0$ in subzero outdoor temperatures (Kuntz 2012).

Limited information exists regarding the ability of ductless mini-splits to effectively dehumidify homes in extremely humid climates ${ }^{11}$ (e.g., the southeastern United States). This topic was analyzed in a presentation given at the 7th Annual North American Passive House Conference, which concluded that an ERV and a single 12,000 Btu/h indoor mini-split unit could provide adequate moisture removal for occupant comfort at design conditions for a theoretical Passive House in Miami, Florida (McKernan 2012). However, an actual Passive House built in Lafayette, Louisiana, with an ERV and single mini-split conditioning the living room had issues with humidity in the upstairs bedrooms, prompting the builder to add a separate dehumidifier (LCP 2012). During the literature review, no case studies were found with field data on mini-split moisture removal and occupant comfort in extremely humid climates. The dehumidification performance of mini-splits is a potential area for future research.

\section{Low-Cost Electric Options}

When examining low-load HVAC technologies from a life-cycle cost perspective, it is important to consider that as loads become smaller, the efficiency of heating/cooling equipment has less of an impact on life-cycle cost. For example, the use of a 1:1 ductless mini-split to displace electric resistance

\footnotetext{
${ }^{11}$ Humid climates require HVAC equipment with low sensible heat ratios (SHRs), which remove more moisture from the air for each ton of cooling capacity. The SHR is defined as the ratio of sensible cooling capacity to total cooling capacity. A low SHR indicates a higher proportion of latent cooling capacity, increasing the relative ability of the equipment to remove moisture from the air.
} 
baseboards as the primary source of heating in existing, single-family homes in the Pacific Northwest reduced space heating electricity consumption by an average of approximately 3,000 kWh per year ${ }^{12}$ (Baylon et al. 2012). At the current average residential electric rate for the Pacific Northwest (approximately $9 \phi / \mathrm{kWh}$ - based on data from the U.S. Energy Information Administration's State Energy Data System; EIA 2013), this equates to a savings of $\$ 270$ per year. The average installed cost of a 1:1 mini-split system is from $\$ 3,000-\$ 5,000$ (NEEA 2012). The heating and cooling loads in a low-load home will be much lower than those of an existing home of similar size in the same climate zone, potentially resulting in reduced annual energy savings and longer payback periods on the mini-split compared with electric baseboard heat (which is less efficient but much cheaper to purchase and install).

A low-load home with a design heating load of $15,000 \mathrm{Btu} / \mathrm{h}$ can be heated with three 1,500-watt $(\sim 5,000 \mathrm{Btu} / \mathrm{h})$ baseboard heaters. According to RSMeans, the total installed cost for a 1,500-watt baseboard heater is $\$ 250$ (RSMeans 2011). A low-installed-cost approach to cooling a low-load home could be a pair of 0.5-ton window-mount or through-the-wall air conditioners (one on each floor, with effective distribution provided by the home's mechanical ventilation system). The RSMeans total installed cost for a 0.5-ton window-mount air conditioner unit is \$400 (RSMeans 2011).

The cost-effectiveness of a mini-split versus a lower-cost option will vary in different parts of the country due to differing climatic conditions and electricity costs. Thus, in regions with low electricity costs and/or minimal heating and cooling loads, less-efficient, lower-cost HVAC technologies may prove to be more cost-effective than higher-efficiency options with higher capital costs.

In moderate climate zones, another simplified option for heating a low-load home is to heat the tempered outdoor air supplied by an HRV/ERV with a supplemental electric resistance element located in the supply air duct downstream of the HRV/ERV. Two Passive Houses in Urbana, Illinois (the "Smith House" and the "Stanton Residence") use this heating technique (PHIUS 2012). An HRV/ERV with supplemental in-duct electric resistance heat can meet the design heating loads for Passive Houses in various climate zones, particularly in International Energy Conservation Code (IECC) climate zones 1-4 (McKernan 2012, ICC 2011).

\section{Split-System Air Conditioners and Heat Pumps}

The most common central equipment type that uses electricity as the energy source for cooling and heating is air-source heat pumps, typically split systems. Heat pumps may use a gas furnace or electric resistance to provide supplemental heating when outside air temperatures are low and the heat pump cannot meet the entire load. Electricity is also used for central air conditioners for cooling only, often integrated with a furnace to provide heating with a shared fan.

All three major U.S. HVAC manufacturers mentioned in the Conventional HVAC Systems section offer split-system air conditioners and heat pumps with nominal capacities from 1.5 to 5 tons (typically available in 0.5-ton increments). Typical single-stage units have advertised seasonal energy efficiency ratios (SEERs) ${ }^{13}$ for the air conditioners from 13 to 21 ; the heat pumps have advertised SEERs from 13 to

\footnotetext{
${ }^{12}$ Cooling energy savings could also be achieved in homes that were using window-mount air conditioners with less-efficient cooling than a mini-split. However, this study only considered heating energy savings.

${ }^{13}$ SEER is the total amount of cooling provided by an air conditioner or heat pump over the cooling season (in Btu) divided by the total electrical energy used to provide the cooling (in W-h).
} 
19 and heating seasonal performance factors (HSPFs) ${ }^{14}$ from 8 to 9.5. All three manufacturers offer twostage units; the smallest two-stage units have a 2-ton nominal capacity. Carrier offers a heat pump with an inverter-driven compressor, which enables fully variable output down to $40 \%$ of its rated capacity. This heat pump has an advertised SEER of 20.5 and an HSPF of 13. The smallest model of Carrier's variable-speed heat pump has a 2-ton nominal capacity; the $40 \%$ minimum output for this unit is 0.8 ton $(9,600 \mathrm{Btu} / \mathrm{h})$. The range of output provided by this heat pump $(9,600-24,000 \mathrm{Btu} / \mathrm{h})$ is appropriate for low-load homes. However, this technology is more expensive than mini-split heat pumps and the lowcost electric options. PNNL contacted two HVAC retailers who sell Carrier's variable-speed heat pump; both retailers quoted an equipment price of \$7,600 for the 2-ton unit. ${ }^{15}$ There are also concerns regarding the ability of currently available small variable-capacity central systems to achieve sufficient airflow to reach the far ends of a home's ductwork system when operating at their minimum thermal outputs. A solution to this issue would be a system of control for the unit in which the fan speed could be set independently of the compressor output providing for a minimum fan speed sufficient to supply for required airflow for a specific home (i.e., field adjustable).

\section{Air-to-Water Heat Pump}

Air-to-water heat pump systems are an electric option for providing combinations of space heating, space cooling, and DHW. The heat pump's outdoor unit extracts heat from the outdoor air and delivers that heat through a refrigerant-to-water heat exchanger contained within an indoor unit. The heated water from the indoor unit is circulated through radiators, ductless fan-coil units, radiant floor tubing, or a hydronic coil in an air-handling unit to provide space heating and can also be circulated through a heat exchanger in a DHW tank to heat the cold city water. (Backup electric resistance elements are often needed to boost the water temperature in the DHW tank during periods of low outdoor temperatures.) Space cooling can be provided by reversing the refrigerant cycle direction and circulating chilled water through a hydronic air-handling unit (which must be equipped with a condensate drain).

There are currently three residential-sized air-to-water heat pump products available in the United States that produce both hot and chilled water: the Unico UniChiller, the Aqua Products Reverse Cycle Chiller, and the Daikin Altherma (Springer et al. 2012). Of these products, the UniChiller and the Reverse Cycle Chiller are intended for space heating and space cooling only, while the Altherma is designed to provide DHW as well. The UniChiller is available in two models (3-ton or 5-ton nominal capacity) that have equipment list prices (not including the cost of the water distribution system or installation) of $\$ 6,800$ and $\$ 8,100 .{ }^{16}$ The Reverse Cycle Chiller is available in package models with 2-ton to 5-ton nominal capacity (Aqua Products 2013). PNNL contacted an HVAC wholesaler who sells the Reverse Cycle Chiller and was quoted an equipment list price of $\$ 16,000$ for the 5 -ton model. ${ }^{17}$ The Altherma comes in models with nominal capacities of 18,000-54,000 Btu/h and has an inverter-driven compressor that enables variable-capacity operation (Daikin 2012). The equipment list price for the

\footnotetext{
${ }^{14} \mathrm{HSPF}$ is the total heat output of a heat pump (including heat provided by the refrigeration cycle and supplemental electric resistance) over the heating season (in Btu) divided by the total electrical energy used to provide the heating (in W-h).

${ }^{15}$ Personal communication between SA Brown (PNNL) and representatives from Total Energy Management, Inc. (Richland, WA) and Apollo Heating \& Air Conditioning (Kennewick, WA). September 20, 2013.

${ }^{16}$ Personal communication between a Unico (St. Louis, Missouri) representative and SA Brown (PNNL). January 17, 2013.

${ }^{17}$ Personal communication between Johnstone Supply store (Kennewick, Washington), and SA Brown (PNNL), January 18, 2013.
} 
smallest Altherma model is $\$ 10,000-\$ 11,000 .{ }^{18}$ Because the installed cost for an air-to-water heat pump system is well above $\$ 10,000$ (probably approaching $\$ 20,000$ ), air-to-water heat pumps are unlikely to be cost-effective compared with other low-load HVAC systems.

\section{Gas Options}

Gas-fired heating options only satisfy the heating needs of homes and must be paired with separate cooling and dehumidification systems, if those are required. Gas-fired equipment can be attractive due to its efficient use of source energy (no efficiency loss through energy conversion at the power plant, and no power distribution losses) and can be more cost-effective in areas with high electricity costs. Similar direct-fire furnace and boiler technologies exist for alternative fuels including wood, propane, and fuel oil. However, these are not discussed here because they are less common and fuel costs can be prohibitively expensive. Direct-vent wall furnaces (DVWFs) are point-source units that provide space heating. Combi systems provide DHW and heating; the heating is typically delivered from a central air system and ductwork. The smallest capacity gas furnaces and boilers can potentially be used for low-load homes as well, particularly equipment with modulating output.

\section{Direct-Vent Wall Furnace}

For cold climates where space cooling is not necessary, a simple gas-fired, space-heating-only option is a direct-vent wall furnace (DVWF). DVWFs are sealed-combustion systems that draw in outdoor air for combustion and send exhaust gases outside. These typically have a coaxial "pipe-in-pipe" exhaust and combustion air supply arrangement that only requires a single penetration through the exterior wall and enables the exiting exhaust gases to pre-warm the incoming combustion air. Although DVWFs are used to heat individual rooms in a typical home, their low outputs make them good candidates for pointsource (in central spaces only) whole-house heating in a low-load home. Outputs of 10,000-40,000 Btu/h are common for DVWFs (MPI 2012; EHS 2012), although Rinnai does offer models with outputs of less than 10,000 Btu/h, the smallest of which has an output range of 2,400-6,400 Btu/h (Rinnai 2012). DVWFs with outputs of 10,000-20,000 Btu/h are available from online vendors in the general price range of \$500-\$1,300 (Bizrate 2013). PNNL spoke with an HVAC contractor in the Seattle area with experience installing Rinnai DVWFs. ${ }^{19}$ The contractor reported that the additional gas piping needed to connect the unit to the home's gas supply can cost between $\$ 300-\$ 1,000$ (depending on the length required) and that the total installed cost could be about $\$ 1,000-\$ 2,500$, although installed cost will vary by region.

During the winter of 2009-2010, CARB investigated the use of single-point heating from a DVWF in four low-load homes that are part of the Wisdom Way Solar Village in Greenfield, Massachusetts (CARB 2010a). The design heat loads of the homes were 10,000-14,000 Btu/h, so a heater was selected that had an output of $16,000 \mathrm{Btu} / \mathrm{h}$ at high-fire and $10,200 \mathrm{Btu} / \mathrm{h}$ at low fire. The heater was installed in the central living space on the first floor, with small crank-timer electric resistance heaters installed for backup comfort purposes in the bathrooms. Exhaust ventilation was provided in the homes by continuously running an upstairs bathroom exhaust fan. To help distribute fresh air (and equalize temperatures within

\footnotetext{
${ }^{18}$ Personal communication between a Daikin engineer and SA Brown (PNNL). January 17, 2013.

${ }^{19}$ Personal communication between A-Hayes Heating \& Cooling (AHHC) representative and SA Brown (PNNL) on January 2, 2013, Richland, Washington.
} 
the home), a small distribution fan was installed that pulls air from the ceiling of the first-floor living space and delivers it to the upstairs bedrooms through small-diameter ducts.

CARB monitored temperature and humidity in the first-floor living space and the bedrooms, using the Air Conditioning Contractors of America (ACCA)-recommended maximum temperature difference of $4^{\circ} \mathrm{F}$ as a comfort standard. In the four homes, the maximum temperature difference was less than $4^{\circ} \mathrm{F}$ for $68 \%, 81 \%, 82 \%$, and $97 \%$ of the time, with the differences between homes due to a combination of differing floor plans, occupancy patterns, internal gains, and occupant behaviors. None of the homeowners had comfort complaints (CARB 2010a). CARB noted that for these Greenfield, Massachusetts (design heating temperature of $2^{\circ} \mathrm{F}$ ) low-load homes, internal gains from a single, awake occupant and electronics/lighting can meet approximately $30 \%$ of the design heating load for a bedroom. For the majority of the heating season, losses through the envelope are considerably lower than at design conditions, so internal gains will meet a greater percentage of, or even the entire, heating load. However, design heating loads typically occur during the night, when internal gains are at a minimum because electronics and lighting are turned off and occupants are asleep. For this reason, the home's HVAC system should still be sized to meet the design load without having to rely on help from internal gains.

\section{Combination Systems}

Combination ("combi”) systems use a single piece of gas-fired heating equipment (e.g., a storage tank water heater, tankless water heater, or boiler) to provide space heating and DHW. Combi systems are a good fit for low-load homes because the instantaneous space heating loads in low-load homes are typically much smaller than water heater capacities. ${ }^{20}$ In a conventional existing home, larger space heating loads make it more difficult for a water heater to provide space heating and DHW.

In retrofit applications, combi systems are attractive because they can replace older, less-efficient furnaces and water heaters with a single high-efficiency heating system, resulting in cost savings compared with replacing each unit individually. The use of a single, sealed-combustion system also improves safety compared with natural draft furnaces and water heaters, which can potentially discharge combustion products into the home if a depressurization occurs in the combustion zone. ${ }^{21}$

A common setup for providing space heating with a combi system is to circulate hot water from the heating equipment through a hydronic coil in an air handler, where heat is transferred to supply air that is distributed throughout the home using a blower and ductwork. Other heating distribution methods such as baseboard fin-tubes, radiators, and radiant floors can be used, but are less common that the hydronic coil air handler setup.

An important initial consideration is the type of heating equipment (e.g., tank or tankless water heater) to use. Tankless water heaters were identified by Building Science Corporation (BSC) as having the performance advantages of high heating capacities and low standby losses compared with storage tank water heaters. BSC evaluated the performance of two combi systems using a tankless water heater and

\footnotetext{
${ }^{20}$ Tankless water heaters have particularly high capacities to enable instantaneous heating of DHW draws. In order to bring a typical (2 gallons per minute) draw of cold water up a $70^{\circ} \mathrm{F}$ temperature rise (for example, from $50^{\circ} \mathrm{F}$ to $\left.120^{\circ} \mathrm{F}\right)$, a tankless water heater must be able to provide $70,000 \mathrm{Btu} / \mathrm{h}$ of heat $(2 \mathrm{gal} / \mathrm{min} \times 60 \mathrm{~min} / \mathrm{hour} \times 8.34 \mathrm{lb} / \mathrm{gal}$ x $70^{\circ} \mathrm{F}$ x $\left.1 \mathrm{Btu} / \mathrm{lb}-{ }^{\circ} \mathrm{F}=70,000 \mathrm{Btu} / \mathrm{h}\right)$. Many tankless water heaters have capacities of 150,000-300,000 Btu/h. Some high-capacity, direct-vent tank water heaters have heat input rates of 100,000 Btu/h.

${ }^{21}$ The combustion zone describes the area near a combustion appliance, particularly natural draft appliances.
} 
hydronic air handler as part of a NYSERDA ${ }^{22}$ retrofit project in Utica, New York (Rudd 2012). The contractor bid for installing these systems was about $\$ 3,500$ per system. ${ }^{23}$

One of the key findings from BSC's research was that combi systems using tankless water heaters work better if a small (6-12 gallon), insulated storage tank is added to the system and kept at a desired setpoint temperature $\left(130^{\circ} \mathrm{F}\right)$ by circulating water through the tankless water heater as needed. The small storage tank serves to provide a "buffer capacity" in the system to make sure that space-heating and water-heating demands can be met simultaneously. ${ }^{24}$ Of two Utica, New York, homes, one system had a small storage tank and the other did not. The system with the storage tank was able to consistently provide supply air temperatures in the range required for comfort $\left(100^{\circ} \mathrm{F}-115^{\circ} \mathrm{F}\right)$, while the system without storage often had supply air temperatures that were too cold (e.g., $70^{\circ} \mathrm{F}-90^{\circ} \mathrm{F}$ ). Occupants in the home without the storage tank also complained about having to wait a long time for their water to become sufficiently warm, while the occupants with the storage tank were satisfied with their hot water supply. The tankless water heater with a small insulated storage tank will still have lower thermal losses than traditional storage tank water heaters and will be able to meet the required water and air temperatures for heating and DHW.

Several other design considerations and concerns related to tankless water heater/hydronic air handler combi systems include tankless water heaters not firing in response to short DHW draws, scale buildup in the system clogging the inlet strainer on the tankless water heater, and the need to periodically circulate water through the heating coil during the non-heating summer months to avoid stagnation and possible growth of Legionella bacteria (Rudd 2012). Regardless of the heating system type, BSC noted that in order to deliver sufficiently high supply air temperatures, the water supplied to the hydronic coil needs to be at higher temperatures (e.g., $130^{\circ} \mathrm{F}-140^{\circ} \mathrm{F}$ ) than those required for DHW applications. When using a condensing water heater, those supply temperatures will generally result in return water temperatures that enable condensing operation (i.e., return water temperatures below $120^{\circ} \mathrm{F}$ ).

Although storage tank water heaters have higher standby losses and lower heating capacities than tankless water heaters, the emergence of direct-vent storage tank water heaters with higher capacities and efficiencies ${ }^{25}$ offers an attractive alternative to tankless systems due to reduced installation complexity and a much larger storage volume that can serve larger combined space heating and DHW draws.

\footnotetext{
${ }^{22}$ New York State Energy Research and Development Authority.

${ }^{23}$ In a study being conducted by the NorthernSTAR Building America Partnership (led by the Minnesota-based Center for Energy and Environment), contractor bids for installing combi systems with a condensing gas heating system coupled to a hydronic air handler ranged from $\$ 6,000-\$ 9,000$ (Schoenbauer et al. 2012). The goal of this work is to retrofit 300 Minnesota homes with combi systems, replacing the existing furnaces with hydronic air handlers coupled to condensing gas heating equipment.

${ }^{24}$ BSC had previously identified the "buffer capacity" provided by a small storage tank as being advantageous in DHW-only tankless systems for instances of sustained, high-volume DHW draws. This recommendation was then carried over into BSC's combi system research. (Personal communication with Dr. John Straube, BSC, and SA Brown, PNNL, September 23, 2013.)

${ }^{25}$ An example is the A.O. Smith Vertex ${ }^{\text {TM }} 100$ water heater, which has an energy factor of 0.96 and an input of 100,000 Btu/h (AOS 2013).
} 


\section{Central Furnaces}

The smallest single-stage high-efficiency condensing gas furnaces have an output of approximately $40,000 \mathrm{Btu} / \mathrm{h}$ and an annual fuel utilization efficiency (AFUE) ${ }^{26}$ of $90 \%$. All three of the major U.S. HVAC manufacturers mentioned in the Conventional HVAC Systems section offer two-stage units, with the smallest two-stage units having a low-fire output of 25,000-35,000 Btu/h. All three manufacturers also offer variable-capacity (a.k.a. "modulating") units that can vary their output down to $35 \%-40 \%$ of their rated output. The smallest variable-capacity units have a minimum output of 22,000-24,000 Btu/h. All of these products are still oversized for a low-load home (design loads of 12,000-24,000 Btu/h; often at partial loads of less than $12,000 \mathrm{Btu} / \mathrm{h}$ ), although the low-fire outputs of the smallest two-stage units and the minimum outputs of the smallest variable-capacity units are approaching the design loads of larger low-load homes.

\section{Boilers}

Although the majority of residential boilers offered by major U.S. HVAC manufacturers are singlestage units with outputs of $30,000 \mathrm{Btu} / \mathrm{h}$ or greater, small modulating boilers with minimum outputs that are within the design heating loads of larger low-load homes are available in the United States. One example product is the Munchkin Boiler model T50MR2 (available from Radiant Heat Products, LLC), which has a fully modulating output from 16,000-46,000 Btu/h and an AFUE of 95\% (RHP 2013). Another example is the Dunkirk VLT-050, a wall-mounted unit with an input rate of 10,000-50,000 $\mathrm{Btu} / \mathrm{h}$ and an AFUE of $95 \%$. There is anecdotal evidence that smaller-sized residential boilers are more common in Europe than in the United States. Further research is needed to inventory available models and identify barriers to implementation in the United States.

\section{Summary and Path Forward}

The literature review identified a number of technologies (summarized in Table 4) that are being used to provide HVAC services in low-load homes. ${ }^{27}$ While information is available regarding the performance of individual technologies/systems in particular situations, no definitive document was identified that presents a side-by-side comparison and evaluation of the various options.

Future work in this area could include the development of a guidance document and/or quantitative tool that would help with the selection of the optimum low-load HVAC system for a given set of circumstances. For example, homeowners in different parts of the United States experience different heating, cooling, and humidity demands as well as differing fuel prices. The characteristics of an individual home (e.g., size, envelope performance, and internal gains from occupants) will dictate the

\footnotetext{
${ }^{26}$ In this context, a high-efficiency furnace is one with an AFUE of at least $90 \%$. The AFUE is the annual ratio of energy that a furnace or boiler provides to the home's distribution system (ductwork or pipes, respectively) compared to the total energy contained in the heating fuel. Condensing gas appliances are those that extract a sufficient amount of heat from the exhaust gases to condense the water vapor produced during combustion.

${ }^{27}$ Table 4 lists key characteristics for typical representative examples of each identified technology. Capacity information is for the smallest identified unit (which is the size that is most applicable to low-load homes). Cost information is often presented as a range because equipment costs vary among manufacturers and installation costs vary for different locations and different contractors. Instances where a single value is provided for cost represent "typical" costs for technologies that are more of a commodity in nature (e.g., window-mount air conditioners and electric baseboard heaters).
} 
necessary HVAC system size. A homeowner's preferences/constraints for the system's fuel type, initial cost, and life-cycle cost will also factor into the selection of the optimum system. The guidance document and selection tool could help homeowners sort through the large number of options and arrive at the system that will suit their needs best.

Another finding from the literature review was that many HVAC systems for low-load homes are custom in nature and are installed by builders who've learned the best installation techniques by trial and error. To achieve Building America's goal of widespread market penetration of energy-efficient homes, it is important that the smaller, non-conventional HVAC systems installed in these homes keep occupants comfortable. With this goal in mind, future work in this area could also include the development of system sizing and installation guidance that is specific to particular low-load HVAC technologies (e.g., mini-split heat pumps or combi systems). This guidance would be similar to the existing manuals for HVAC system selection and sizing that are published by ACCA, and might ultimately be developed as an ACCA document in order to take advantage of ACCA's large existing reader base and maximize dissemination to builders across the United States. 
Table 4. Comparison of Low-Load HVAC Technologies

\begin{tabular}{|c|c|c|c|c|c|}
\hline System Types & Capacity of Smallest Available Unit & Efficiency & Cost & Pros & Cons \\
\hline $\begin{array}{l}\text { Condensing Gas Furnace - } \\
\text { Two Stage }\end{array}$ & $\begin{array}{c}\text { 40,000 Btu/h high fire, } 25,000 \mathrm{Btu} / \mathrm{h} \\
\text { low fire }\end{array}$ & $90-96 \%$ & $\$ 900$ to $\$ 1000$ & $\begin{array}{l}\text { compromise on price and performance, central } \\
\text { air distribution }\end{array}$ & $\begin{array}{l}\text { low-fire is still oversized for majority of } \\
\text { hours in low-load homes }\end{array}$ \\
\hline $\begin{array}{l}\text { Condensing Gas Furnace - } \\
\text { Modulating }\end{array}$ & $60,000 \mathrm{Btu} / \mathrm{h} \max 22,000 \mathrm{Btu} / \mathrm{h} \min$ & $90-98.5 \%$ & $\sim \$ 1,400$ & $\begin{array}{l}\text { lowest part load, highest efficiency, central air } \\
\text { distribution }\end{array}$ & highest cost furnace option \\
\hline $\begin{array}{l}\text { Condensing/Modulating } \\
\text { Boiler }\end{array}$ & $\begin{array}{l}46,000 \mathrm{Btu} / \mathrm{h} \max \\
10,000 \mathrm{Btu} \min \end{array}$ & $90-95 \%$ & $\$ 2,000$ to $\$ 3,000$ & $\begin{array}{l}\text { central air or hydronic distribution; } \\
\text { appropriately sized output for low-load homes }\end{array}$ & $\begin{array}{l}\text { not commonly used in the U.S.; lack of } \\
\text { familiarity might cause installation or } \\
\text { maintenance concerns. }\end{array}$ \\
\hline $\begin{array}{l}\text { Split System AC- Single } \\
\text { Stage (central ducted) }\end{array}$ & 1.5 tons & SEER $13-21$ & $\sim \$ 700$ to $\$ 1,000$ & low cost; provides central air distribution & $\begin{array}{l}\text { requires separate heating system; } \\
\text { possible short cycling, humidity issues }\end{array}$ \\
\hline $\begin{array}{l}\text { Split System Heat Pump - } \\
\text { Single Stage (central } \\
\text { ducted) }\end{array}$ & 1.5 tons & $\begin{array}{l}\text { SEER 13-19; } \\
\text { HSPF 8-9.5 }\end{array}$ & $\sim \$ 2,000$ & least expensive heat pump & possible short cycling, humidity issues \\
\hline $\begin{array}{l}\text { Split System Heat Pump - } \\
\text { Inverter Driven } \\
\text { (central ducted) }\end{array}$ & $\begin{array}{c}0.8-2 \text { tons } \\
9,600-24,000 \mathrm{Btu} / \mathrm{h}\end{array}$ & $\begin{array}{l}\text { SEER 20.5; } \\
\text { HSPF } 13\end{array}$ & $\sim \$ 7,600$ & $\begin{array}{l}\text { best central heat pump sizing/performance for } \\
\text { low-load homes }\end{array}$ & $\begin{array}{l}\text { high cost; airflow concerns when } \\
\text { operating at minimum output }\end{array}$ \\
\hline Ductless Mini-Split & $\begin{array}{c}\text { 9,000 Btu/h full load, } 2,800 \mathrm{Btu} / \mathrm{h} \\
\text { minimum }\end{array}$ & $\begin{array}{l}\text { SEER 15-25; } \\
\text { HSPF 9-10 }\end{array}$ & $\$ 3,000$ to $\$ 6,000$ & $\begin{array}{l}\text { appropriate size for low-load homes; high } \\
\text { efficiency at part-load conditions, good } \\
\text { performance at low temperatures. }\end{array}$ & $\begin{array}{l}\text { wall unit fan noise, aesthetics, but can } \\
\text { conceal in short duct }\end{array}$ \\
\hline $\begin{array}{l}\text { Window Unit Air } \\
\text { Conditioner }\end{array}$ & 0.5 ton & $\begin{array}{l}\text { EER } \sim 10 \\
\text { (average new } \\
\text { unit) }\end{array}$ & $\sim \$ 400$ & simple system, distributed points & lower efficiency \\
\hline $\begin{array}{l}\text { Baseboard Electric } \\
\text { Resistance }\end{array}$ & $1,500 \mathrm{Btu} / \mathrm{h}$ & near $100 \%$ & $\sim \$ 250$ & simple system, distributed points & $\begin{array}{l}\text { low efficiency compared with heat } \\
\text { pumps }\end{array}$ \\
\hline $\begin{array}{l}\text { In-Duct Electric Resistance } \\
\text { Element }\end{array}$ & $\begin{array}{c}1 \mathrm{~kW} \text { (typical small-end of product } \\
\text { offerings) }\end{array}$ & near $100 \%$ & $\$ 200$ to $\$ 400$ & can be integrated with ERV/HRV & $\begin{array}{l}\text { low efficiency compared with heat } \\
\text { pumps }\end{array}$ \\
\hline Direct-Vent Wall Furnace & $\begin{array}{l}2,400 \mathrm{Btu} / \mathrm{h} \text { (smallest available); } \\
\text { typical small size } \sim 10,000 \mathrm{Btu} / \mathrm{h}\end{array}$ & $80 \%-95 \%+$ & $\begin{array}{c}\$ 1,500 \text { to } \$ 2,500 \text { for } \\
10,000 \mathrm{Btu} / \mathrm{h} \text { to } 20,000 \\
\mathrm{Btu} / \mathrm{h}\end{array}$ & $\begin{array}{l}\text { simple, low-cost system for point-source } \\
\text { heating }\end{array}$ & $\begin{array}{l}\text { distribution concerns, connecting unit to } \\
\text { house gas lines can increase installation } \\
\text { cost depending on unit's location in the } \\
\text { home }\end{array}$ \\
\hline Combi System & $\begin{array}{l}\text { wide range of water heater sizes can } \\
\text { be used (typical tankless WH: } 100- \\
300 \mathrm{kBtu} / \mathrm{h} \text {; typical high-capacity, } \\
\text { direct-vent tank WH: } 70-100 \mathrm{kBtu} / \mathrm{h}\end{array}$ & typically $90 \%+$ & $\$ 3,500-\$ 9,000$ & $\begin{array}{l}\text { heating and DHW with single high-efficiency } \\
\text { system }\end{array}$ & complex design, maintenance \\
\hline Air-to-Water Heat Pump & $18,000 \mathrm{Btu} / \mathrm{h}$ & $\begin{array}{c}\text { EER } \sim 7-12 \\
\text { COP (heating) } \\
\sim 3-4 \\
\text { COP (DHW) } \\
\sim 2-4\end{array}$ & $\sim \$ 10,000$ to $\$ 20,000$ & $\begin{array}{l}\text { heating, cooling, and DHW with single high- } \\
\text { efficiency system }\end{array}$ & $\begin{array}{l}\text { very high cost; complex design, } \\
\text { maintenance }\end{array}$ \\
\hline
\end{tabular}




\section{References}

AOS -A.O. Smith Corporation. 2013. Vertex ${ }^{\mathrm{TM}} 100$ Power Direct Vent 50-Gallon Gas Water Heater. Accessed September 2013 at http://www.hotwater.com/water-

heaters/residential/conventional/gas/vertex/power-direct-vent/

Aqua Products Company, Inc. 2013. Reverse Cycle Chiller. Product literature provided upon request from Toisha Bumgarner, Purchasing/Shipping Manager, Aqua Products Company, Inc. January 18, 2013.

Bailes A. 2012. Mechanical Systems for Low-Load Buildings. GreenBuildingAdvisor.com, December 26, 2012. Accessed January 2013 at http://www.greenbuildingadvisor.com/blogs/dept/building-science/mechanical-systems-low-loadbuildings.

Baylon D, B Larson, P Storm, and K Geraghty. 2012. Ductless Heat Pump Impact \& Process Evaluation: Field Metering Report. Ecotope, Inc., Seattle, Washington. Accessed December 2012 at http://neea.org/docs/reports/ductless-heat-pump-impact-process-evaluation-field-meteringreport.pdf?sfvrsn=16.

Bizrate. 2013. Bizrate.com pricing results for natural gas direct-vent wall furnaces with an output of 10,000-20,000 Btu/h. Accessed January 2013 at http://www.bizrate.com/heaters/direct-vent-wallfurnace/natural-gas/10-000-20-000/349729-435407/633649-633685/buy?show=40\&sort=5.

CARB - Consortium for Advanced Residential Buildings. 2010a. Point-Source Heating Systems in Cold-Climate Homes: Wisdom Way Solar Village. October 15, 2010. Norwalk, Connecticut. Accessed December 2012 at http://carb-

swa.com/articles/advanced\%20systems\%20research/room_heaters_adv_system.pdf.

CARB - Consortium for Advanced Residential Buildings. 2010b. Systems Evaluation: Mini-Split Heat Pumps in Cold-Climate Home Katywil Community, Colrain, MA. October 12, 2010. Norwalk, Connecticut. Accessed December 2012 at http://carbswa.com/articles/advanced\%20systems\%20research/Mini-Split\%20Heat\%20Pumps\%20in\%20ColdClimate\%20Home.pdf.

Daikin. 2012. Daikin Altherma Engineering Data. Accessed December 2012 at http://www.daikinac.com/DOC/DACA-EEDEN11-720\%20Daikin\%20Altherma\%20Engineering\%20Data.pdf.

DOE - U.S. Department of Energy. 2011. Technical Support Document: Energy Efficiency Program for Consumer Products: Residential Central Air Conditioners, Heat Pumps, and Furnaces. U.S. Department of Energy, Washington D.C.

EHS - Empire Heating Systems. 2012. Small Direct-Vent Wall Furnaces. Accessed December 2012 at http://www.empirezoneheat.com/ehs/index.php?view=direct-vent-wall-furnace\# (undated webpage).

EIA - U.S. Energy Information Administration. 2013. Rankings: Average Retail Price of Electricity to Residential Sector, October 2012 (cents/kWh). Accessed February 2013 at http://www.eia.gov/beta/state/rankings/?sid=US\#/series/31 (undated webpage). 
EIA - U.S. Energy Information Administration. 2012. 2009 Residential Energy Consumption Survey (RECS) Data.

EPA - U.S. Environmental Protection Agency. 2012. A Brief Guide to Mold, Moisture, and Your Home: Mold Basics. Accessed January 2013 at http://www.epa.gov/mold/moldbasics.html (last updated March 5, 2012).

Holladay M. 2012. Just Two Minisplits Heat and Cool the Whole House. GreenBuildingAdvisor.com. August 17, 2012. Accessed January 2013 at http://www.greenbuildingadvisor.com/blogs/dept/musings/just-two-minisplits-heat-and-cool-whole-house International Code Council (ICC). 2011. 2012 International Energy Conservation Code. International Code Council, Country Club Hills, Illinois.

Kuntz M. 2012. Ductless Heat Pumps for Passive Houses. 7th Annual North American Passive House Conference. September 27-30, 2012. Accessed December 2012 at http://www.passivehouse.us/phc2012/2012\%20Presentations/Kuntz-Mitsubishi-PHIUS.pdf.

LCP - Low Carbon Productions. 2012. Interview: Corey Saft, Passive House Builder, Lafayette, Louisiana. February 17, 2012. Accessed January 2013 at http://www.lowcarbonproductions.com/2012/02/interview-corey-saft-passive-house-builder-lafayettelouisiana/.

McKernan KM. 2012. Climate Influences on the Mechanical System of a Passive House. 7th Annual North American Passive House Conference. September 27-30, 2012. Accessed December 2012 at http://www.passivehouse.us/phc2012/2012\%20Presentations/McKernan_Climate\%20Influences\%20on\% 20the\%20Mechanical\%20System\%20of\%20a\%20PH_Denver\%202012.pdf

Mitsubishi - Mitsubishi Electric. 2009a. Submittal Data: MSZ-FE09NA \& MUZ-FE09NA. Copyright Mitsubishi Electric, HVAC Advanced Products Division, 2009. Accessed November 2012 at http://www.mitsubishicomfort.com/flash/airhunter/assets/pdf/MSZ-FE09NA MUZFE09NA_Submittal.pdf.

Mitsubishi - Mitsubishi Electric. 2009b. Submittal Data: MSZ-FE12NA \& MUZ-FE12NA. Copyright Mitsubishi Electric, HVAC Advanced Products Division, 2009. Accessed November 2012 at http://www.mehvac.com/UploadedFiles/Resource/MSZ-FE12NA MUZ-FE12NA_Submittal.pdf.

Mitsubishi - Mitsubishi Electric. 2012. Outdoor Single-Zone Units. Accessed December 2012 at http://www.mitsubishicomfort.com/en/consumer/product-solutions/product-showcase/outdoor-singlezone-units (undated webpage).

MPI - Monitor Products, Inc. 2012. Monitor Gas Products. Accessed December 2012 at http://www.monitorheat.com/gas_products.html (undated webpage).

NEEA - Northwest Energy Efficiency Alliance. 2012. Cost of Installation [for ductless heating and cooling systems]. Accessed December 2012 at http://goingductless.com/consumer/about-ductlessheating-and-cooling/costs. 
NREL - National Renewable Energy Laboratory. 2008. National Solar Radiation Data Base 1991-2005 Update: Typical Meteorological Year 3. Accessed July 2013 at http://rredc.nrel.gov/solar/old_data/nsrdb/1991-2005/tmy3/

NREL - National Renewable Energy Laboratory. 2012. Building America Summer 2012 Technical Update Meeting Report. Accessed January 2013 at http://www.nrel.gov/docs/fy13osti/56639.pdf.

PHIUS - Passive House Institute US. 2012. Certified PHIUS Projects. Accessed December 2012 at http://www.passivehouse.us/projects.php (undated webpage).

RHP - Radiant Heat Products, LLC. Munchkin Boilers. Accessed January 2013 at http://munchkinboiler.net/ (undated webpage).

Rinnai - Rinnai Corporation. 2012. Direct Vent Wall Furnaces. Accessed December 2012 at http://www.rinnai.us/direct-vent-wall-furnace (undated webpage).

Rosenbaum M. 2010. Heating and Cooling Systems: Micro Systems for Micro Loads. South Mountain Company. ACI New England, October 6-7, 2010. Accessed November 2012 at http://acinewengland.org/sites/default/files/session/79250/ne10max1rosenbaum.pdf.

RSMeans. 2011. RSMeans Mechanical Cost Data, $35^{\text {th }}$ Annual Edition. MJ Mossman, C Babbitt, and T Baker (eds.) Norwell, Massachusetts.

Rudd A. 2012. Measure Guideline: Combination Forced-Air Space and Tankless Domestic Hot Water Heating Systems. August 2012. Accessed December 2012 at

http://apps1.eere.energy.gov/buildings/publications/pdfs/building_america/measure_guide_combi_system s.pdf $\% 20$.

Ruiz FP. 2012. Building America Meeting Touches on Ventilation/Insulation Debate. Ecohome Magazine, September 25, 2012. Accessed January 2013 at http://www.ecohomemagazine.com/greenbuilding/building-america-meeting-touches-on-ventilationin.aspx.

Rutkowski H. 1997. "Manual RS Minimum Performance Standards for Comfort and Safety." Section 1, pages 9-10 of Manual RS: Comfort, Air Quality, and Efficiency by Design. Air Conditioning Contractors of America Educational Institute, Washington, D.C.

Rutkowski H. 2006. "Table 1A: Outdoor Design Conditions for the United States." Page 230 of Manual J: Residential Load Calculations, Eighth Edition, Version Two. Air Conditioning Contractors of America, Arlington, VA.

Schoenbauer B. 2012. Combi Systems for Low Load Homes. Presentation at Building America Summer 2012 Technical Update Meeting. Accessed January 2013 at http://apps1.eere.energy.gov/buildings/publications/pdfs/building_america/issue7_combi_systems.pdf.

Schoenbauer B, D Bohac, P Huelman, R Olson, and M Hewitt. 2012. Retrofitting Combined Space and Water Heating Systems: Laboratory Tests. NorthernSTAR Building America Partnership, St. Paul, Minnesota. Accessed December 2012 at http://www.nrel.gov/docs/fy13osti/55482.pdf. 
Springer D, D Dakin, and C Backman. 2012. A Feasibility Study: Ductless Hydronic Distribution Systems with Fan Coil Delivery. Alliance for Residential Building Innovation (ARBI), Davis, California. Accessed January 2013 at http://apps1.eere.energy.gov/buildings/publications/pdfs/building_america/ductless_hydronic_dist.pdf.

Stecher D. 2011. Final Expert Meeting Report: Simplified Space Conditioning Strategies for Energy Efficient Houses. Prepared by IBACOS, Inc., for the U.S. Department of Energy Building America Program, Pittsburgh, Pennsylvania. Accessed November 2012 at http://apps1.eere.energy.gov/buildings/publications/pdfs/building_america/52160.pdf.

Stecher D. 2012. Minimized Space Conditioning Distribution Strategy for Low-load Homes.

Presentation at Building America Summer 2012 Technical Update Meeting. Accessed December 2012 at http://apps1.eere.energy.gov/buildings/publications/pdfs/building_america/issue7.space_cond.pdf.

Straube J. 2012. What are the Best HVAC Solutions for Low-Load, High Performance Homes?

Presentation at Building America Summer 2012 Technical Update Meeting. Accessed December 2012 at http://apps1.eere.energy.gov/buildings/publications/pdfs/building_america/issue7.hvac_lowload.pdf. 


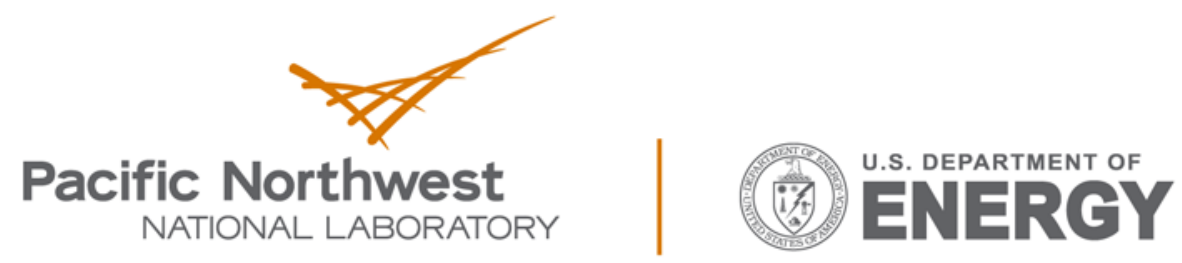

Proudly Operated by Battelle Since 1965

902 Battelle Boulevard

P.O. Box 999

Richland, WA 99352

1-888-375-PNNL (7665)

www.pnnl.gov 